\title{
Development of a Freshman Engineering Measurements and Analysis Course Integrated with Calculus-based Statistics
}

\author{
Jon H. Marvel, Charles R. Standridge \\ Grand Valley State University
}

Introduction

As part of the freshman course sequence, a laboratory based introductory engineering measurements course is required of all engineering majors in the Padnos School of Engineering at Grand Valley State University. The course, which requires that the students have successfully completed Calculus I prior to enrolling, meets twice a week, once for two hours of lecture and once for a three-hour laboratory.

The course was developed around hypothetical "cases" that the students might encounter during their co-op assignments with the local industries. As an integral part of the undergraduate engineering degree, the Padnos School of Engineering requires that all students successfully complete three semesters of co-operative education with local industry. These cases introduce a problem that requires the students to make measurements in a laboratory situation using a variety of equipment commonly used in engineering environments. The students will analyze the measurement data to address specific questions posed in the case descriptions and submit their analysis in a formal written and/or oral report. This course was redesigned from an introductory engineering statistics course to an engineering measurements based course in order to provide motivation and a context as realistic as possible for data collection and the application of statistics.

During the lecture portion of the course, the current case and development of necessary theoretical background are introduced. Statistical tools and measurement techniques required to address the problem posed in the case are presented. Cooperative learning techniques are employed wherever they are appropriate to introduce the students to the equipment and techniques required in laboratory as well as to practice the statistical procedures required to address the problems.

The balance of this paper describes the arrangement and description of the cases, topics, and laboratory experiments integrated into the course design.

\section{Course Overview}

The objectives for this course are for students; 1) to be able to perform fundamental statistical analysis to data acquired from both engineering experimentation and supplied data sets; 2) to demonstrate an understanding of basic mechanical and electrical concepts needed to make 
engineering measurements, and 3) to be proficient in communicating the results of an experiment through writing laboratory reports and delivering oral presentations. Based on these objectives, the course has been developed based on seven hypothetical industry case problems. These case problems were developed to simulate typical assignments that the students might experience during their co-op assignments. Another reason for the development of these case problems was to introduce material and concepts, at a basic level, which the students will be exposed to in greater detail during their sophomore year.

In order to solve each of the case problems, the students must master measurement concepts, statistical concepts and analysis techniques. A summary of the cases is shown in Table 1. The lecture component of the course introduces the measurement and statistical concepts while the lab component allows the student to collect the data required to provide an answer to the questions posed in the case problem description.

Table 1 - Case Overview

\begin{tabular}{|c|c|c|c|}
\hline Case Description & $\begin{array}{l}\text { Measurement } \\
\text { Concept }\end{array}$ & $\begin{array}{c}\text { Statistical concept } \\
\text { and/or analysis } \\
\text { technique }\end{array}$ & Laboratory Experiment \\
\hline $\begin{array}{l}\text { Process Variability } \\
\text { and Direct } \\
\text { Measurement }\end{array}$ & $\begin{array}{ll}- & \text { Measurement } \\
\text { terminology } \\
\text { - } & \text { Use of Vernier } \\
\text { calipers }\end{array}$ & $\begin{array}{l}\text { Descriptive } \\
\text { statistics } \\
\text { including } \\
\text { histograms, } \\
\text { boxplots, and } \\
\text { run charts } \\
\end{array}$ & $\begin{array}{l}\text { - Assess variability of } \\
\text { steel washers through } \\
\text { direct measurement of } \\
\text { thickness using a } \\
\text { Vernier caliper }\end{array}$ \\
\hline $\begin{array}{l}\text { Linear Regression } \\
\text { and Indirect } \\
\text { Measurement }\end{array}$ & $\begin{array}{ll}- & \text { Propagation of } \\
\text { error } \\
\text { - } & \text { Use of mass } \\
\text { scale }\end{array}$ & $\begin{array}{ll}- & \text { Linear } \\
& \text { regression }\end{array}$ & 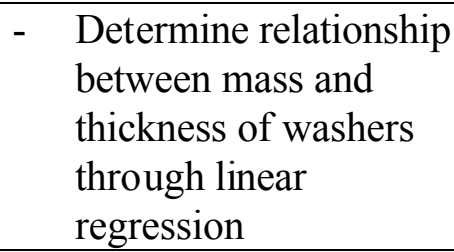 \\
\hline Probability Concepts & $\begin{array}{ll}\text { - } & \text { Standard coding } \\
\text { for resistors } \\
\text { - } & \text { Equivalent } \\
& \text { resistance of } \\
\text { resistors in series } \\
\text { and parallel } \\
\text { - } & \text { Use of digital } \\
\text { multi-meter to } \\
\text { measure } \\
\text { electrical } \\
\text { quantities }\end{array}$ & $\begin{array}{ll}\text { - } & \text { Central limit } \\
\text { theorem }\end{array}$ & 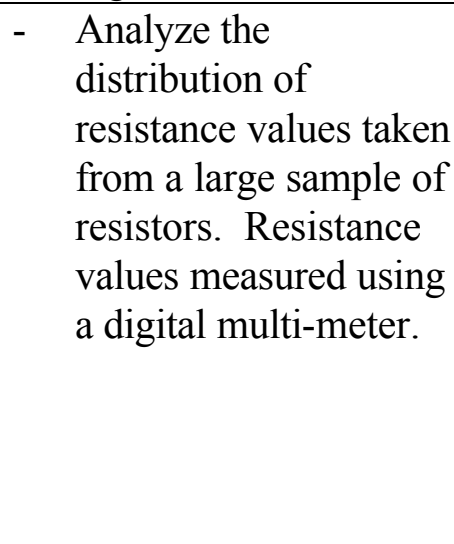 \\
\hline
\end{tabular}


Table 1 - Case Overview (con't)

\begin{tabular}{|c|c|c|c|}
\hline Case Description & $\begin{array}{l}\text { Measurement } \\
\text { Concept }\end{array}$ & $\begin{array}{l}\text { Statistical concept } \\
\text { and/or analysis } \\
\text { technique }\end{array}$ & $\begin{array}{l}\text { Laboratory } \\
\text { Experiment }\end{array}$ \\
\hline $\begin{array}{l}\text { Power Measurement } \\
\text { and Ohm's Law }\end{array}$ & \begin{tabular}{|ll}
- & Ohm's Law \\
- & Relationship \\
& between voltage, \\
& current, and \\
power
\end{tabular} & $\begin{array}{ll}\text { - } & \text { Confidence } \\
& \text { intervals } \\
\text { - } & \text { Point estimates }\end{array}$ & $\begin{array}{l}\text { Analyze the power } \\
\text { developed in a solar } \\
\text { panel by measuring } \\
\text { the voltage and } \\
\text { current in solar } \\
\text { panel circuit }\end{array}$ \\
\hline $\begin{array}{l}\text { Convection Heat } \\
\text { Transfer }\end{array}$ & - Thermocouples & 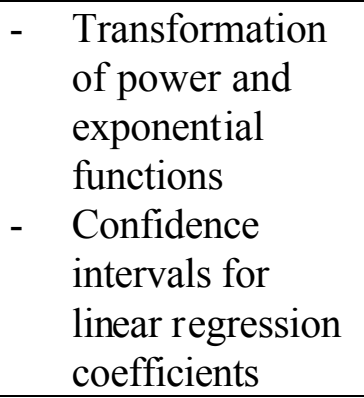 & $\begin{array}{l}\text { Analyze the } \\
\text { convection heat } \\
\text { transfer mechanism } \\
\text { and determine the } \\
\text { cooling rate of a } \\
\text { heated aluminum } \\
\text { rod }\end{array}$ \\
\hline $\begin{array}{l}\text { Strain } \\
\text { Measurements from } \\
\text { Cantilever Beam in } \\
\text { Bending }\end{array}$ & 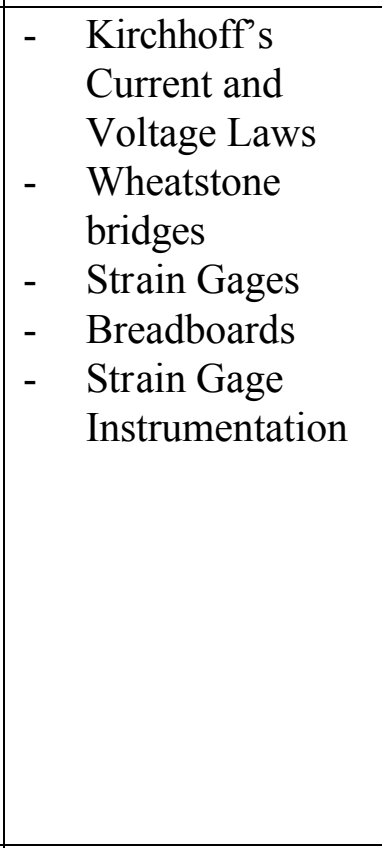 & 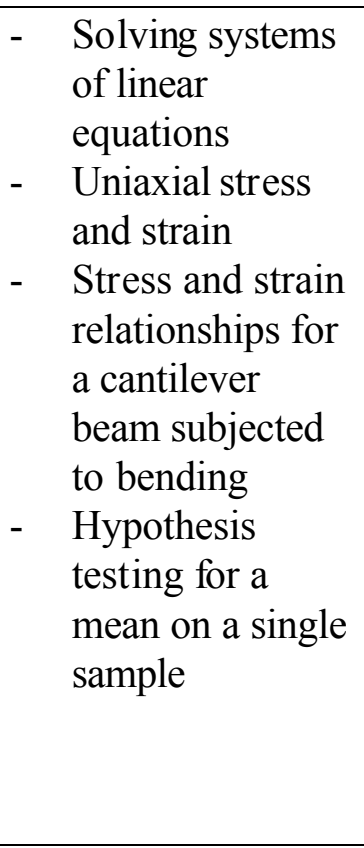 & $\begin{array}{l}\text { Verify Kirchhoff's } \\
\text { Laws by building } \\
\text { breadboard circuits } \\
\text { and comparing } \\
\text { actual and } \\
\text { theoretical values of } \\
\text { currents and } \\
\text { voltages } \\
\text { - Analyze Wheatstone } \\
\text { bridge equations by } \\
\text { building bridge } \\
\text { circuits } \\
\text { - Measure strain in a } \\
\text { cantilever beam } \\
\text { subjected to bending } \\
\text { and compare results } \\
\text { to theoretical model }\end{array}$ \\
\hline $\begin{array}{l}\text { Gage Repeatability } \\
\text { and Reproducibility }\end{array}$ & \begin{tabular}{|ll}
- & Repeatability \\
& and \\
& Reproducibility \\
- & Use of \\
& micrometers and \\
& Vernier calipers \\
\end{tabular} & $\begin{array}{l}\text { Hypothesis } \\
\text { testing on the } \\
\text { difference in the } \\
\text { means of two } \\
\text { populations } \\
\text { using paired data }\end{array}$ & $\begin{array}{ll}\text { - } & \text { Perform a Gage } \\
\text { R\&R study using } \\
\text { micrometers and } \\
\text { Vernier calipers }\end{array}$ \\
\hline
\end{tabular}




\section{Description of Case Studies}

\section{Case 1: Process Variability and Direct Measurement}

The introductory case problem in the course identifies a situation in which the variability in the thickness of steel washers has caused problems in downstream operations in the assembly process. The student is asked to assess the variability in the thickness from a sample of washers. The measurement concepts that are introduced include accuracy, precision, and uncertainty. The students must use a Vernier caliper to collect the data during the lab session ${ }^{2}$. The lecture component of the course introduces basic statistical methodology used to assess variability such as histograms, boxplots, and run charts. Summary statistics that identify location and data spread are also introduced. After the students have collected the data in the laboratory they are asked to write a report about their analysis of the variability of the washer thickness.

\section{Case 2: Linear Regression and Indirect Measurement}

This case problem introduces the concept of indirect measurement. The case problem asks students to determine the relationship between the mass of the washer and the thickness. The measurement concepts introduced include propagation of uncertainty. The lecture portion of the course also introduces linear regression. During the laboratory experiment, the students measure the mass of the washers, whose thickness they had previously measured, using a mass scale. Linear regression is then used to determine the relationship between the mass and thickness of the washers ${ }^{2}$. The student must address questions such as the calculation of the uncertainty in the thickness measurement due to the uncertainty in the mass measurement and the calculation of the standard deviation of the thickness based on the standard deviation of the mass measurement.

\section{Case 3: Probability Concepts}

The third case problem introduces the use of probability concepts to answer questions related to products that are created from a sequence of electrical resistors in parallel and series. The measurement concepts that are introduced include the use of digital multi-meters (DMM) to measure electrical quantities and the classification and color-coding of electrical resistors. The statistical concepts introduced include probability density and cumulative distribution functions, the central limit theorem, the Lilliefors test to assess whether or not data is consistent with a normal distribution, and the theorem on the additivity of random normal variables. The laboratory exercise requires that the students analyze devices made up of sets of parallel and series resistors and answer questions regarding the normality of measured resistances as well as questions related to the probabilities that these sets of resistors meet or exceed specified equivalent resistances ${ }^{2}$.

\section{Case 4: Power Measurement and Ohm's Law}

The focus of the case problem on power measurement asks the students to determine the maximum power output of a solar panel. The measurement concepts reinforced in the case are Ohm's Law and the relationship between power, voltage, and current. The statistical concepts introduced in the lecture are the calculation and interpretation of confidence intervals and point estimates. During the lab exercise, the students build a solar panel circuit such that the voltage across and the current flowing through the resistor can be measured ${ }^{2}$. The students then determine the maximum power provided by the solar panel. Confidence intervals are calculated 
to determine whether or not the solar cell meets the manufacturers specification for maximum power.

\section{Case 5: Convection Heat Transfer}

The objective in this case problem is to determine the cooling characteristics of an aluminum rod. The mathematical model for heat convection is introduced in order to expose students to nonlinear system responses. The use and operation of thermocouples are presented. The statistical or analytical concepts discussed in the lecture include the transformation of power and exponential relationships into linear relationships. The transformation of non-linear functions into linear functions allows the analysis and development of the theoretical model of the data via linear regression and then transformation back into the power or exponential form. Additionally, confidence intervals about the linear regression coefficients are also introduced. The laboratory experiment entails the heating of an aluminum rod and the measurement of the temperature decay as a function of time and wind tunnel speed. The students analyze the data and calculate the heat transfer coefficient and compare this value to published data.

Case 6: Stress and Strain Measurements from a Cantilever Beam in Bending

The objective of this case study is for the students to understand how to use strain gages to build a mass scale including the circuitry involved. The measurement concepts developed in this case include: Kirchhoff's Current and Voltage Laws for analyzing a resistive circuit, the application and operation of Wheatstone bridge circuits, and the fundamental theory behind the operation of strain gages. Some of the statistical and analysis techniques include: matrix methods for solving systems of linear equations, the relationship between uniaxial stress and strain, stress and strain relationships for a cantilever beam subjected to bending, and hypothesis testing for a mean on a single sample. Three laboratory experiments supported this case problem. First, students verify Kirchhoff's Current and Voltage Laws by building circuits on breadboards. The students analyze the theoretical and actual currents and voltages in the circuits and explain any discrepancies. The second laboratory experiment requires the students to build Wheatstone bridge circuits on the breadboards and determine the resistance value of the unknown leg in the circuit. The students then compare the value of the resistance determined from the bridge circuit analysis to the direct measurement of the unknown resistance though the use of a DMM. The final laboratory experiment requires the student to measure the strain developed in a cantilever beam subjected to bending. Students used strain gage instrumentation and compare the theoretical model to actual strain measurements.

\section{Case 7: Gage Repeatability and Reproducibility}

This case problem focused on the quality of measurement devices. The students assessed which was the better instrument for measuring the outside diameter of a PVC tube, a micrometer or a Vernier caliper, by performing a Gage R\&R study ${ }^{2}$. The measurement concepts introduced included the definition and calculation of repeatability and reproducibility. Additional statistical concepts of hypothesis testing on the difference in the means of two populations using paired data were also presented. 


\section{Summary and Future Directions}

The initial offering of the redesigned course was delivered to approximately 50 students during the Fall 2002 semester. A comparison assessment of the prior course and the redesigned course is extremely difficult at best. The courses have fundamentally different objectives and educational requirements. The previous course was focused on a laboratory-based experience in engineering statistics. The redesigned course focuses on engineering measurement techniques. The fundamental strategy change is to teach how engineers acquire and use data. Thus the statistics is taught in the context of its engineering application and not in isolation merely as a useful methodology.

After the initial offering of the redesigned course, students were asked to provide feedback on the course design. The student feedback was positive and indicated that the significant amount of hands-on data collection and use of laboratory equipment were important elements in understanding statistical analysis methodology. Students who were aware that previous offerings of the course included analysis of supplied data sets or data sets that were downloaded from a website identified the increased amount of hands-on data collection as having a significant impact on their understanding of the course material. Minor modifications were made to the course prior to its second offering to approximately 100 students in the Winter 2003 semester.

The future directions for this course include the publication of a textbook. Since this course covers such a wide array of topics there is no textbook available for the course. A set of course notes ${ }^{1}$ was developed to cover the topics in the course. These course notes will be expanded into a full textbook over the next few years.

\section{Bibliography}

1. Marvel, J. M. and Standridge C.R., 2003. Measurement, Instrumentation, and Experimentation: A First Co-op Experience, Winter 2003, Padnos School of Engineering, Grand Valley State University, Grand Rapids, MI.

2. Standridge C.R. and Marvel, J.M., "Engineering Statistics as a Laboratory Course", Proceedings of the 2002 American Society of Engineering Education Annual Conference and Exposition.

3. Vardeman, S. B. and J. M. Jobe, Basic Engineering Data Collection and Analysis, Duxbury, 2001

\section{JON H. MARVEL}

Jon H. Marvel is an Assistant Professor of Engineering at Grand Valley State University. He holds a BE from Stevens Institute of Technology, an MS from the University of Michigan and a Ph.D. the University of Cincinnati. His is primary responsible for the development of the undergraduate and graduate production operations sequences courses as well as other fundamental courses in the manufacturing engin eering curriculum.

\section{CHARLES R. STANDRIDGE}

Charles R. Standridge is responsible for the development of the lecture and, in partnership with Jon Marvel, the laboratory material for the freshman course discussed in this paper. In addition, he develops teaching approaches for systems simulation courses for undergraduate and graduate students in manufacturing engineering as well as simulation-based approaches to industrial problems in supply chain operations. 